Journal Sosial Science and Teknology for Community Service (JSSTSCS)

Vol. 1, No. 2, September 2020, page-page. 01 09

P-ISSN: 2723-2026

E-ISSN: $2723-455 x$

DOI: -

available online at: https://ejurnal.teknokrat.ac.id/index.php/teknoabdimas

\title{
SISTEM INFORMASI GEOGRAFIS PEMETAAN WILAYAH KELAYAKAN TANAM TANAMAN JAGUNG DAN SINGKONG PADA KABUPATEN LAMPUNG SELATAN
}

\author{
Debby Alita ${ }^{1}$, Irwan Tubagus ${ }^{2}$, Yuri Rahmanto ${ }^{3}$, Styawati $^{4}$, Andi Nurkholis ${ }^{5}$ \\ Universitas Teknokrat Indonesia ${ }^{12345}$
}

Email : debbyalita@teknokrat.ac.id ${ }^{1}$

\begin{tabular}{lll}
\hline Received: (date month year) & Accepted: (date month year) & Published : (date month year ) \\
\hline
\end{tabular}

\begin{abstract}
Based on data on maize and cassava agricultural products at the South Lampung Provincial Agriculture Office, which is sourced from data from BPS (Central Statistics Agency), it shows several areas with varying amounts of maize and cassava yields. In connection with the variation in the number of land or producing areas for maize and cassava, and how to optimize the potential of corn and cassava farming for investors, information on potential maize and cassava producing areas is needed to find out which areas produce corn and cassava in large or small quantities. Evaluation of land suitability is essential for productive and sustainable land use planning.

The use of computer-based technology to support planning is increasingly needed to analyze, manipulate and present information in tabular and spatial form.

Based on this, a Geographical Information System (GIS) is needed to provide information on the mapping of maize and cassava producing areas in South Lampung district, so that areas that produce corn and cassava in large or small quantities can be identified. This research proposes a web-based geographic information system to determine the feasibility of planting corn and cassava plants in South Lampung Regency. GIS that is built on a web basis will be easy to use anywhere and anytime by using the use of internet technology.
\end{abstract}

Keywords: Information Systems, Mapping Areas, Feasibility of Planting Plants

\begin{abstract}
Abstrak
Berdasarkan data hasil pertanian jagung dan singkong di Dinas Pertanian Provinsi Lampung Selatan yang bersumber dari data BPS (Badan Pusat Statistik), menampilkan beberapa daerah dengan hasil panen jagung dan singkong yang bervariasi jumlahnya. Sehubungan dengan bervariasinya jumlah lahan atau daerah penghasil jagung dan singkong, dan bagaimana pengoptimalan potensi tani jagung dan singkong untuk investor, maka diperlukan informasi daerah potensial penghasil jagung dan singkong untuk mengetahui daerah mana saja yang menghasilkan jagung dan singkong dengan jumlah banyak ataupun sedikit. Evaluasi kesesuaian lahan sangat diperlukan untuk perencanaan penggunaan lahan yang produktif dan lestari.

Penggunaan teknologi berbasis computer untuk mendukung perencanaan tersebut semakin diperlukan untuk menganalisis, memanipulasi dan menyajikan informasi dalam bentuk table dan keruangan.

Berdasarkan hal tersebut dibutuhkan Sistem Informasi Geografis (SIG) dapat dimanfaatkan sebagai informasi pemetaan daerah penghasil jagung dan singkong di kabupaten Lampung Selatan, sehingga dapat diketahui daerah yang menghasilkan jagung dan singkong dengan jumlah banyak ataupun sedikit. Pada penelitian ini mengusulkan sebuah Sistem Informasi Geografis menentukan kelayakan tanam tanaman jagung dan singkong pada Kabupaten Lampung Selatan berbasis web. SIG yang dibangun berbasis web akan mudah digunakan dimanapun dan kapanpun dengan menggunakan pemanfaatan teknologi internet.
\end{abstract}

Kata Kunci: Sistem Informasi, Pemetaan wilayah, Kelayakan Tanam Tanaman. 
To cite this article:

Authors. (Year). Title of the article. Journal of Technology and Social for Community Service (JTSCS), Vol(1), Page-Page.

\section{PENDAHULUAN}

Lahan pertanian merupakan lahan yang ditujukan untuk dijadikan lahan usaha tani atau bercocok tanam, untuk memproduksi tanaman pertanian maupun hewan ternak (Sitanggang et al., 2020). Lahan pertanian juga menjadi salah satu sumber daya utama pada usaha pertanian. Lahan pertanian yang paling pokok saat ini adalah pertanian tanaman pangan dengan jenis tanaman yang mengandung karbohidrat dan protein, tanaman pangan dapat dikatakan sebagai tanaman utama yang dikonsumsi manusia sebagai makanan untuk memberikan asupan energi bagi tubuh.

Kaitan dengan lahan pertanian tersebut, dibutuhkan pengetahuan lahan dari berbagai segi, baik dari segi luas lahan, lokasi, potensi yang ada, dan ekosistem yang berkembang. Kebutuhan akan pengetahuan lahan pertanian ini bermanfaat bagi petani yang akan melakukan cocok tanam diwilayahnya. Menurut (Darwis, 2016) hal yang harus diperhatikan tentang tanah sebagai syarat yang baik untuk pertanaman jagung dan singkong adalah $\mathrm{pH}$ tanah optimal yaitu $\mathrm{pH}$ 5,5 - 6,5.Jagung dan singkong dapat tumbuh baik pada daerah dataran rendah maupun dataran tinggi dengan ketinggian antara 800-1800 meter di atas permukaan laut. Karakteristik lahan yang mempengaruhi kelas "sangat sesuai", kelas "cukup sesuai” serta kelas "sesuai marginal" diantaranya temperatur, curah hujan, drainase, tekstur, pH, kedalaman efektif, C- organik, KTK Liat, kemiringan, ketinggian dan erosi. Temperatur yang optimal berkisar antara $26^{\circ} \mathrm{C}$ sangat diperlukan untuk perkembangan dan pertumbuhan tanaman jagung, distribusi curah hujan yang merata sepanjang tahun yaitu antara 807-1200 mm (Wirosoedarmo et al., 2011).

Berdasarkan data hasil pertanian jagung dan singkong di Dinas Pertanian Provinsi Lampung Selatan yang bersumber dari data BPS (Badan Pusat Statistik), menampilkan beberapa daerah dengan hasil panen jagung dan singkong yang bervariasi jumlahnya. Sehubungan dengan bervariasinya jumlah lahan atau daerah penghasil jagung dan singkong, dan bagaimana pengoptimalan potensi tani jagung dan singkong untuk investor, maka diperlukan informasi daerah potensial penghasil jagung dan singkong untuk mengetahui daerah mana saja yang menghasilkan jagung dan singkong dengan jumlah banyak ataupun sedikit. Evaluasi kesesuaian lahan sangat diperlukan untuk perencanaan penggunaan lahan yang produktif dan lestari. Penggunaan teknologi berbasis computer untuk mendukung perencanaan tersebut semakin diperlukan untuk menganalisis, memanipulasi dan menyajikan informasi dalam bentuk table dan keruangan. Salah satu teknologi tersebut adalah Sistem Informasi Geografi (SIG) yang memiliki kemampuan membuat model yang memberikan gambaran, penjelasan dan perkiraan dari suatu kondisi factual (Rahmanto and Hotijah, 2020).

Oleh karena itu, dibutuhkan system informasi geografis yang dapat memberikan informasi lahan pertanian pangan jagung dan singkong secara geografis. Sistem Informasi Geografis (SIG) merupakan suatu sistem yang meng-capture, mengintegrasikan, memanipulasi, menganalisa, dan menampilkan data secara spasial (keruangan) mereferensi kepada kondisi bumi (Pasaribu, 2019). SIG pengintegrasian operasi-operasi umum database, seperti query dan analisa statistik, dengan kemampuan visualisasi dan analisa yang unik yang dimiliki oleh pemetaan (Borman et al., 2018). Kemampuan SIG berbeda dengan system informasi lainnya, SIG dapat memberikan informasi peta antara lain memetekan letak, memetakan kuantitas, memetakan perubahan lokasi, dan memetakan apa yang ada di dalam dan di luar suatu area.

Berdasarkan hal tersebut dibutuhkan Sistem Informasi Geografis (SIG) dapat dimanfaatkan sebagai informasi pemetaan daerah penghasil jagung dan singkong di kabupaten Lampung Selatan, sehingga dapat diketahui daerah yang menghasilkan jagung dan singkong dengan jumlah banyak ataupun sedikit. Pada penelitian ini mengusulkan sebuah Sistem Informasi Geografis menentukan kelayakan tanam tanaman jagung dan singkong pada Kabupaten Lampung Selatan berbasis web. SIG yang dibangun berbasis web akan mudah digunakan dimanapun dan kapanpun dengan menggunakan pemanfaatan teknologi internet.

\section{METODE PELAKSANAAN}

\section{Tempat dan Waktu}

Kegiatan ini dilaksanakan di Dusun IV Sarirejo Natar Lampung Selatan yang dilaksanakan pada tanggal 11 Juli 2020 


\section{Khalayak Sasaran}

Sasaran kegiatan ini adalah masyarakat desa sarirejo Dusun IV untuk dapat memanfaatkan aplikasi GIS dalam menentukan kelayakan tanam jagung dan singkong.

\section{Metode Pengabdian}

\subsection{Teknik Pengumpulan Data}

Metode pengumpulan data yang dilakukan yaiu dengan cara :

1. Wawancara (Interview)

Metode pengumpulan data atau informasi dilakukan dengan cara bertanya langsung kepada Badan Pusat Statiktik (BPS) Lampung Selatan.

2. Tinjauan Pustaka (Literature Review)

Metode pengumpulan data dilakukan dengan cara mempelajari berbagai laporan-laporan ilmiah, jurnal dan doumen atau sumber bacaan serta buku-buku yang berkaitan atau berhubungan dengan topik usulan penelitian.

\subsection{Rancangan Proses}

Rancangan proses merupakan tahapan dalam pengembangan sistem dimulai dari awal hingga akhir proses (Alita, Fernando and Sulistiani, 2020). Rancangan sistem UML (Unified Modelling Language) yang digunakan sebagai pemodelan dan komunikasi antara sistem dengan pengguna. UML (Unified Modelling Language) pada penelitian ini terdiri dari use case, class diagram, sequence diagram. Usecase merupakan visualisasi yang menggambarkan beberapa actor pada system (Ariyanti, 2020)

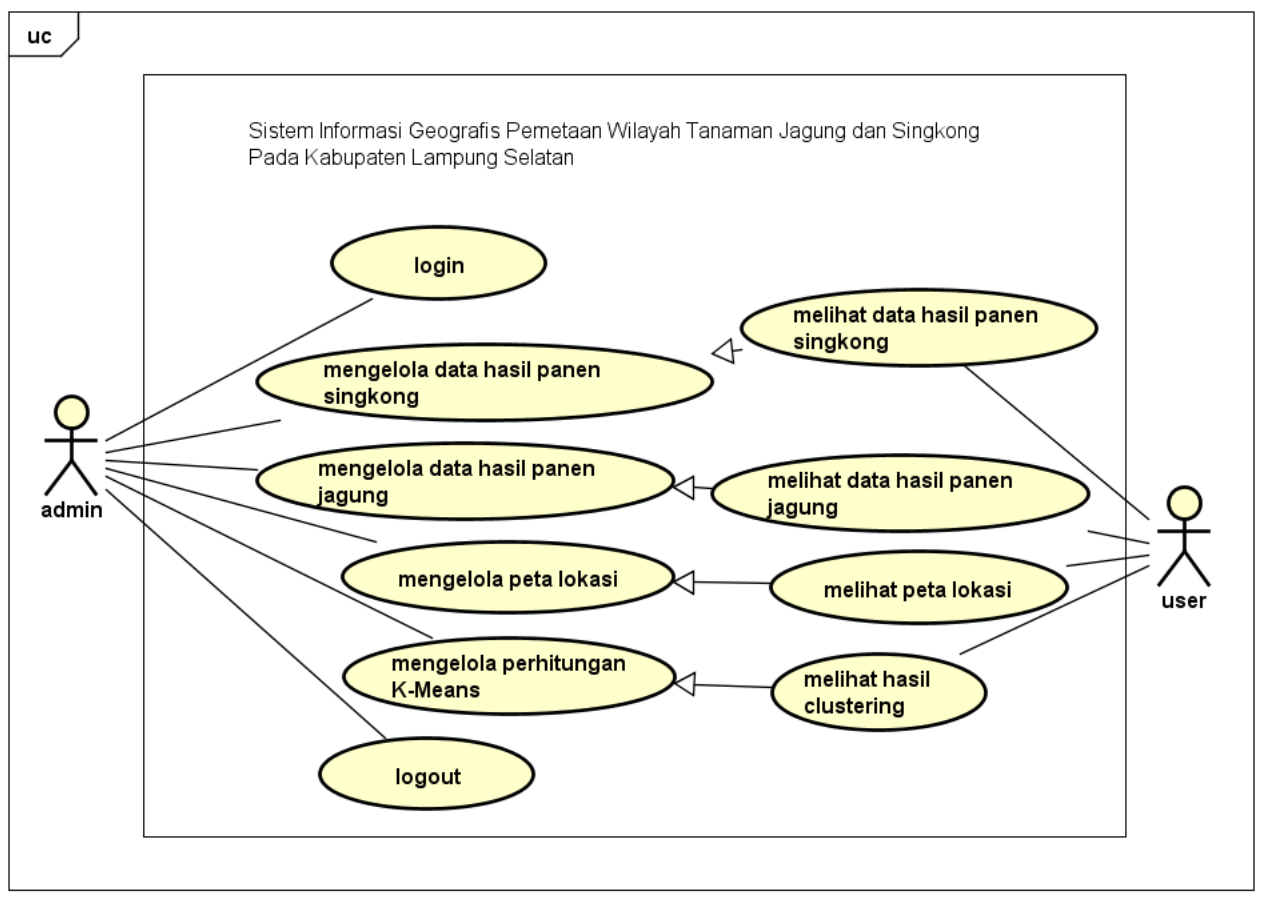

Keterangan :

Gambar 1. Use Case Diagram

1. Admin

a. Pada rancangan sistem, admin harus melakukan login terlebih dahulu untuk mendapatkan hak akses admin. 
b. Admin dapat mengelola data hasil panen, dimana admin memiki hak akses penuh dari sistem ini. Sehingga admin dapat menambahkan, menghapus, mengubah, melihat, dan mencari data hasil panen.

c. Admin dapat mengelola data kecamatan, admin memiliki hak akses penuh dari sistem. Sehingga admin dapat menambah, menghapus, mengubah, melihat, dan mencari data kecamatan.

d. Admin dapat mengelola peta lokasi. Data lokasi berdasarkan hasil panen disetiap kecamatan.

2. User

a. User atau pengguna dapat melihat data hasil panen.

b. User atau pengguna dapat melihat data kecamatan.

c. User dapat melihat peta lokasi.

\section{HASIL DAN PEMBAHASAN}

Hasil implementasi sistem kelayakan tanaman singkong dan jagung menggunakan perhitungan K-Means. Proses pembuatan sistem dilakukan dengan merancang sistem menggunakan rancangan model UML (Unified Modelling Language) yaitu usecase dan juga rancangan tampilan sistem. Rancangan yang telah dibangun kemudian diimplementasikan kedalam kode program menggunakan bahasa pemrograman PHP untuk membangun sistem berbasis Web. Sistem kelayakan tanaman singkong dan jagung berbasis web ini dapat digunakan oleh admin dan pengguna sistem yang dapat digunakan oleh masyarakat luas.

1. Menu Utama

Menu utama merupakan tampilan utama pada saat membuka sistem. Menu utama ini menampilkan beberapa menu lain yang ada pada sistem. tampilan menu utama ini dapat dilihat pada Gambar 2.

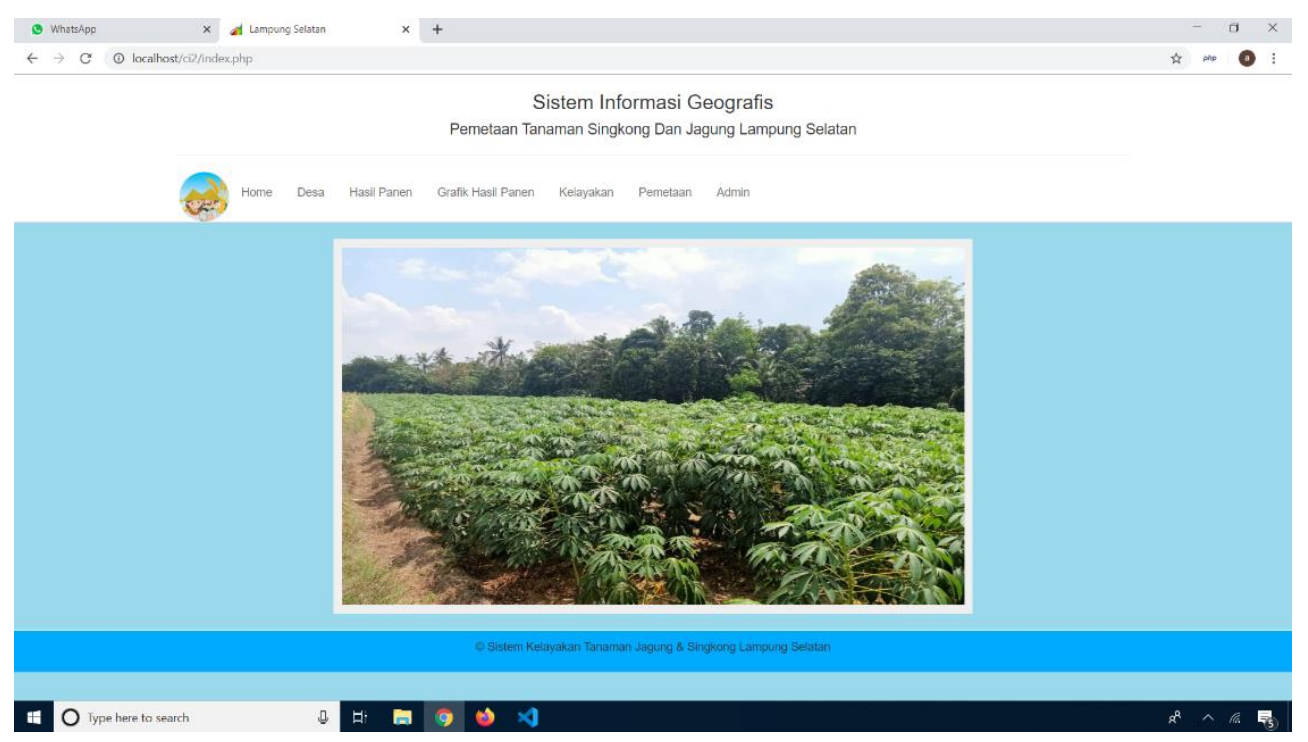

Gambar 2. Menu Utama

\section{Menu Data Desa}

Menu desa merupakan halaman yang menampilkan data desa yang terdapat pada sistem. Tampilan menu desa dapat dilihat pada Gambar 3 


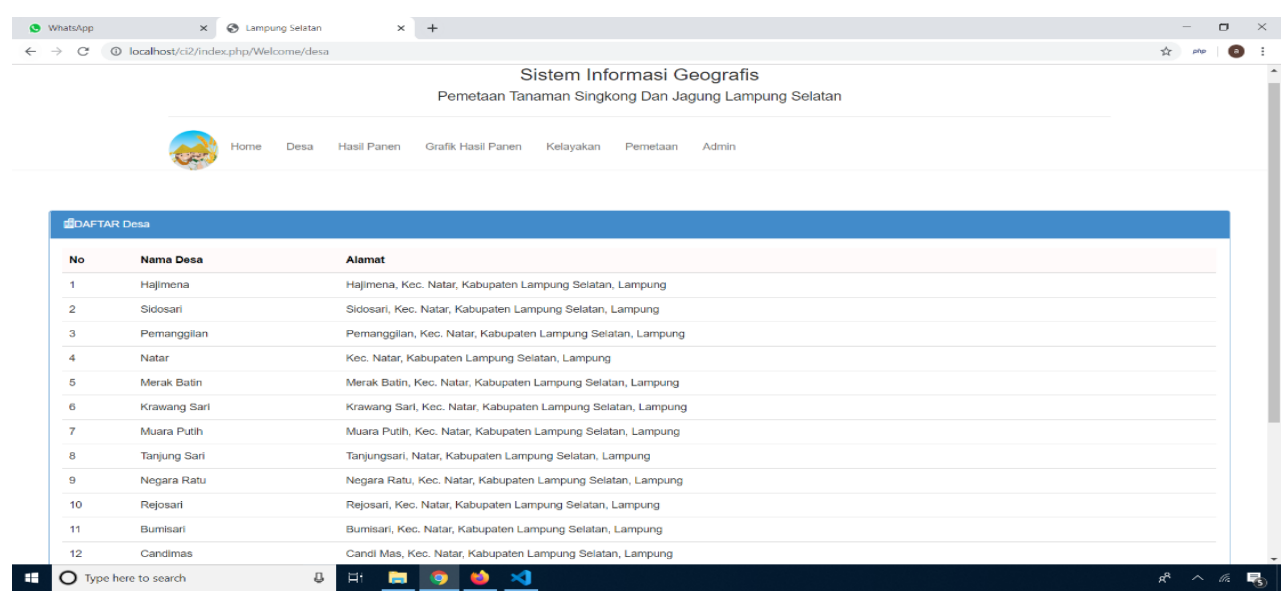

3. Menu Hasil Panen

Gambar 3. Menu Desa

Menu hasil panen merupakan halaman yang menampilkan data hasil panen tanaman jagung dan singkong pada kecamatan Lampung Selatan. Tampilan menu hasil panen dapat dilihat pada Gambar 4.

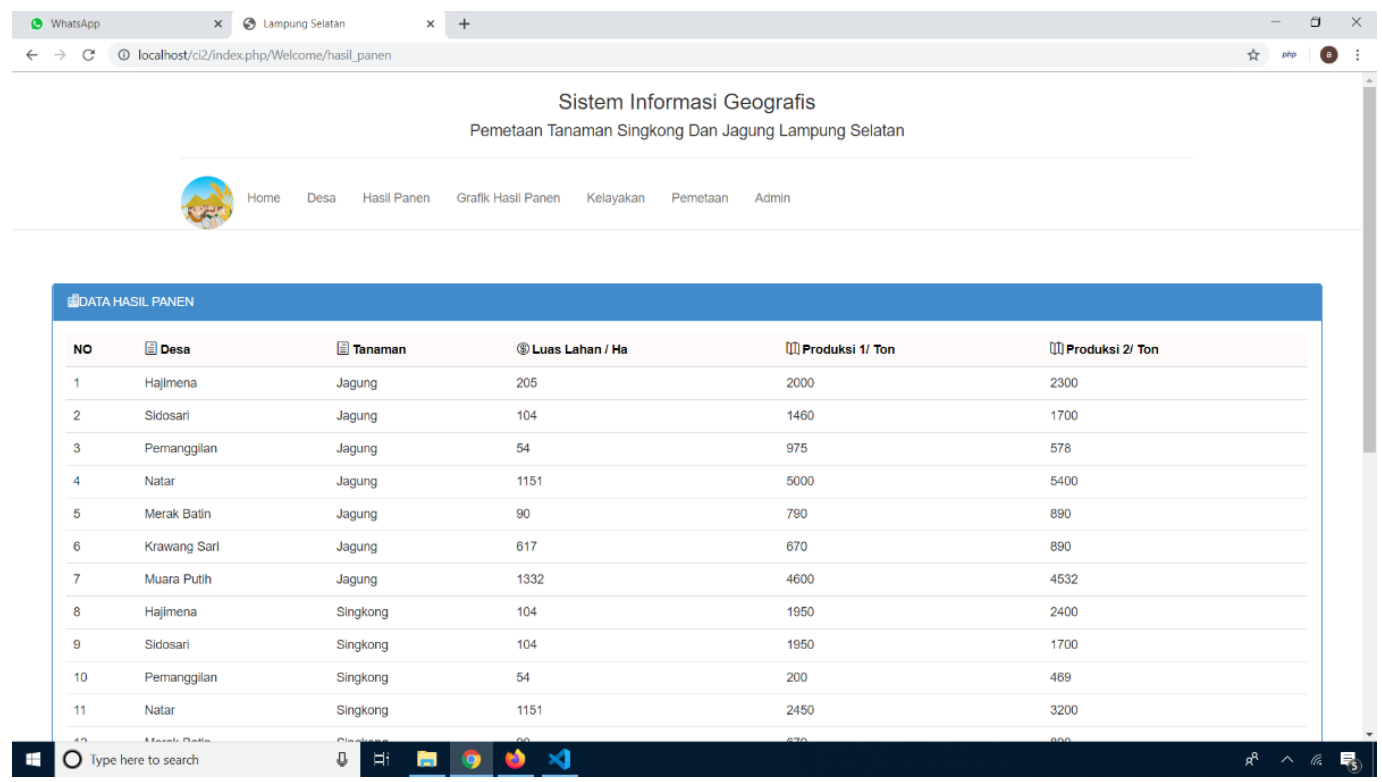

Gambar 4. Menu Hasil Panen

4. Menu K-Means

Menu k-means merupakan halaman untuk perhitungan kelayakan tanaman jagung atau singkong pada setiap daerah. Pada menu perhitungan K-Means terdiri dari beberapa field yaitu kecamatan, hasil perhitungan 1, hasil perhitungan 2, keterangan kelayakan, dan terdapat tombol lihat map, hitung, dan hapus data. Tampilan menu k-means dapat dilihat pada Gambar 5. 


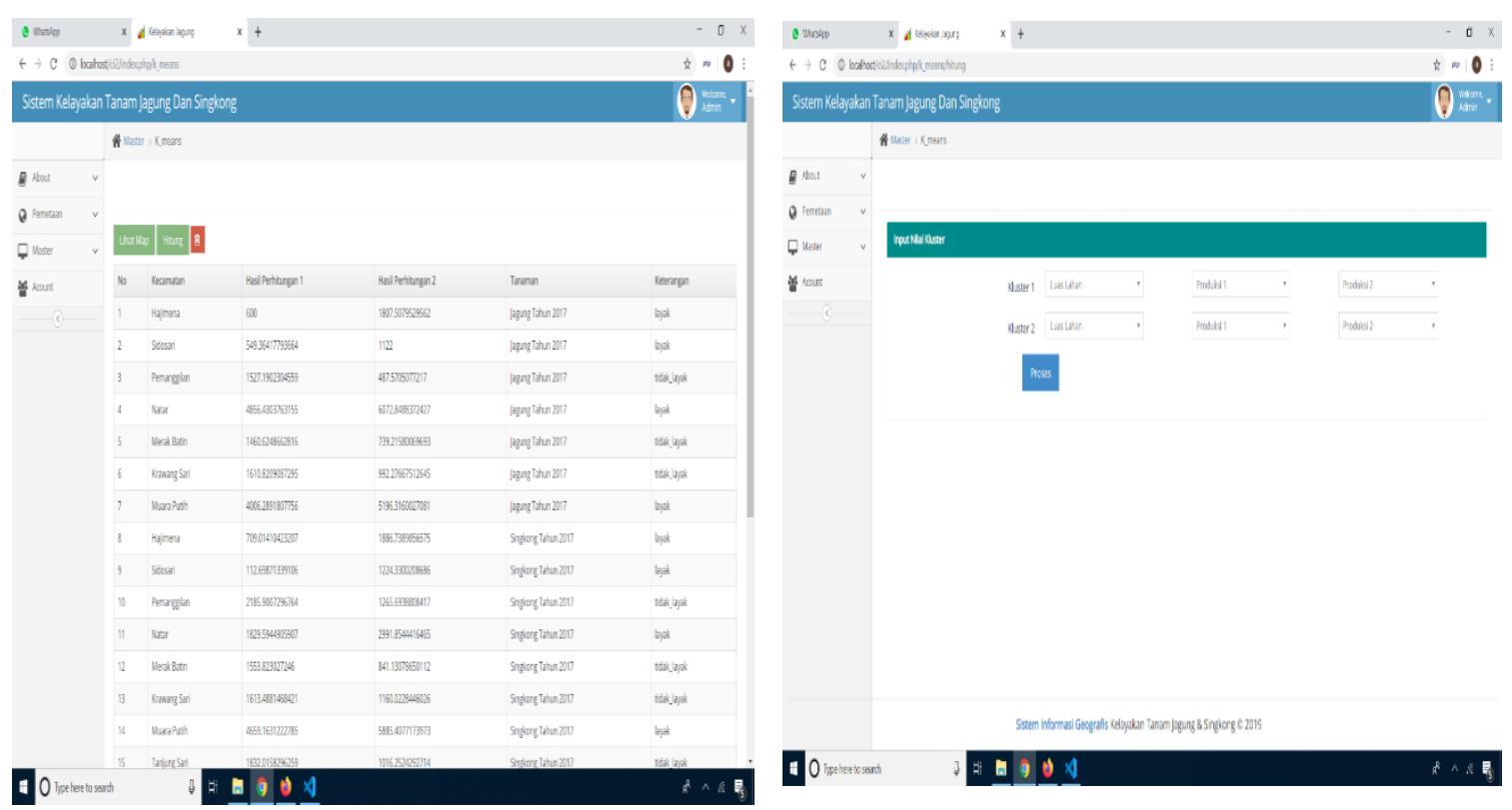

Gambar 5. Menu Perhitungan K-Means

5. Menu Grafik Hasil Panen

Menu hasil panen merupakan halaman yang menampilkan data hasil panen tanaman jagung dan singkong pada kecamatan Lampung Selatan. Tampilan menu hasil panen dapat dilihat pada Gambar 6.

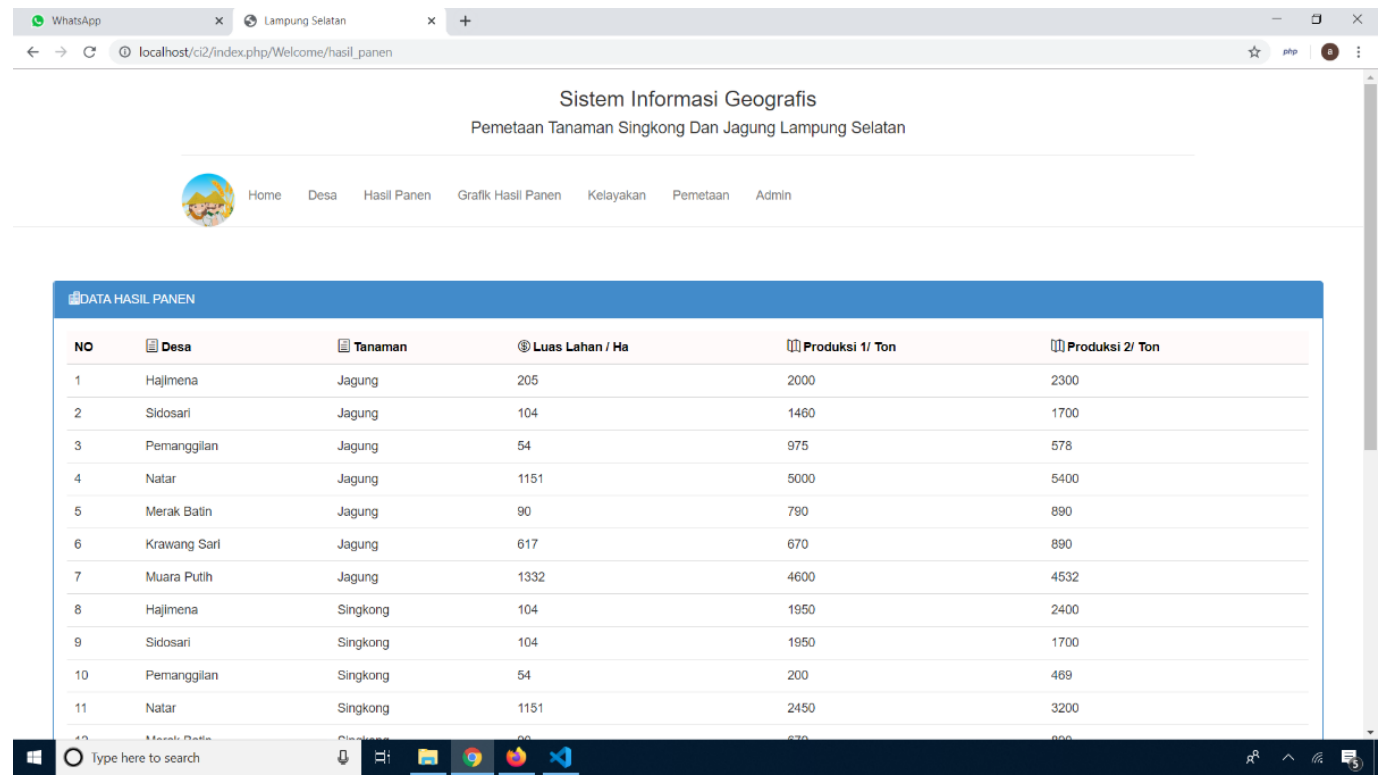

Gambar 6. Menu Hasil Panen

6. Menu Kelayakan

Menu kelayakan merupakan halaman yang menampilkan data kelayakan panen tanaman singkong dan jagung. Tampilan menu kelayakan dapat dilihat pada Gambar 7. 


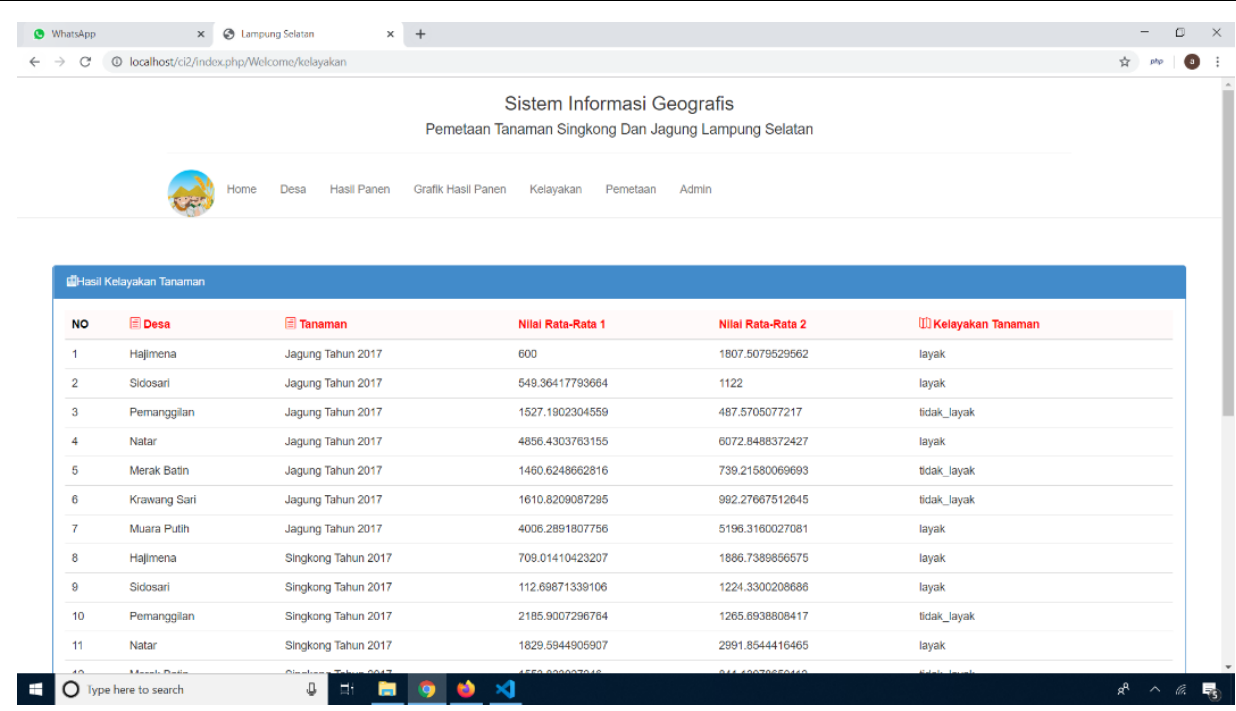

Gambar 7. Menu Kelayakan

\section{Menu Pemetaan}

Menu pemetaan merupakan halaman yang menampilkan peta kelayakan tanaman singkong dan jagung. Tampilan menu pemetaan dilihat pada Gambar 8.

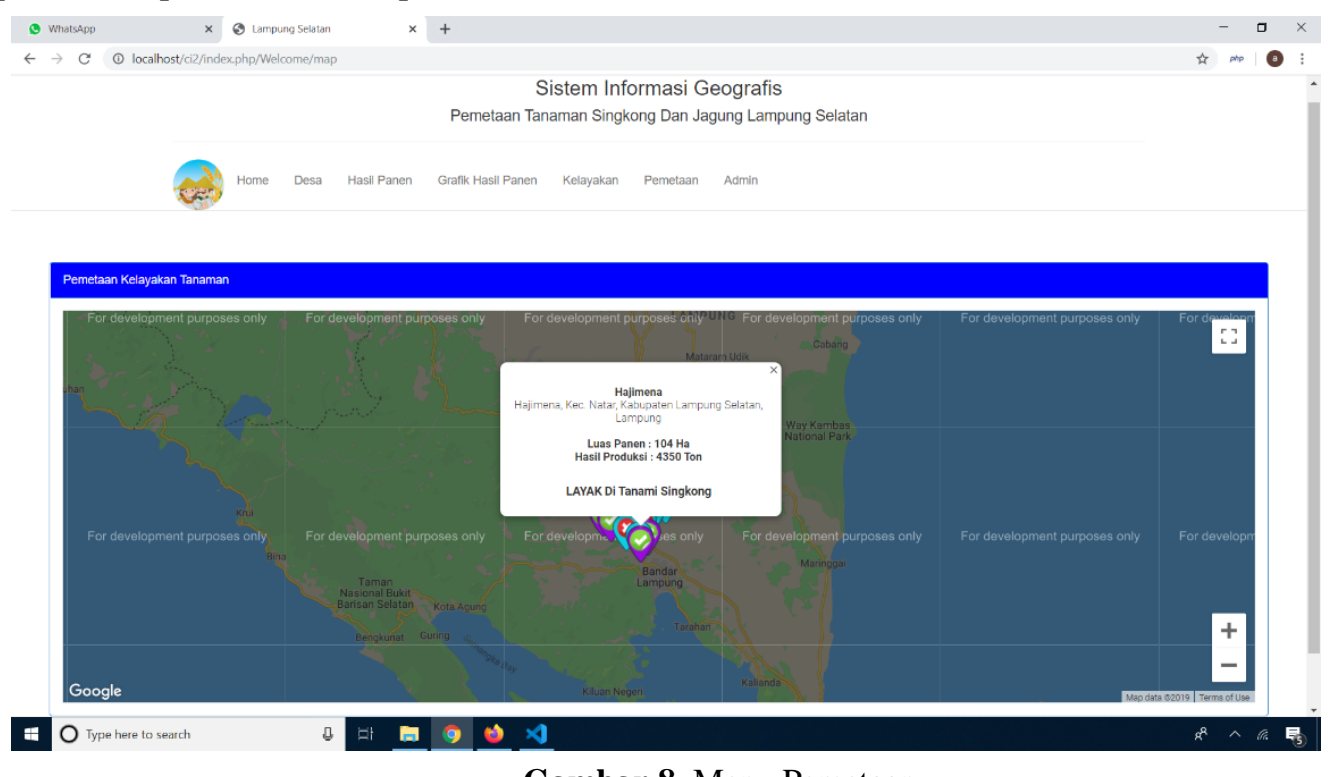

Gambar 8. Menu Pemetaan

\section{KESIMPULAN}

Hasil pembuatan sistem yang telah dibangun, sistem dapat menampilkan data hasil panen dan dapat menampilkan lokasi layak tanam singkong atau jagung dalam bentuk peta (sistem informasi geografis). Berdasarkan hasil pengujian menggunakan pengujian blackbox terhadap fungsionalitas sistem tanpa menguji kode program, seluruh fungsi yang terdapat pada sistem dapat berjalan dengan baik atau sukses, sehingga fungsional sistem secara keseluruhan dapat berfungsi dengan baik dan dapat digunakan tanpa memiliki cacat pada fungsionalitas. 


\section{REFERENSI/DAFTAR PUSTAKA (11 PT)}

Sitanggang, I. S. et al. (2020) 'Garlic Land Suitability System based on Spatial Decision Tree', (Conrist 2019), pp. 206-210. doi: 10.5220/0009908002060210.

Darwis, D. (2016). Aplikasi Kelayakan Lahan Tanam Singkong Berdasarkan Hasil Panen Berbasis Mobile. Jurnal Teknoinfo, 10(1), 6-10.

Pasaribu, A. F. O., Darwis, D., Irawan, A., \& Surahman, A. (2019). Sistem Informasi Geografis untuk Pencarian Lokasi Bengkel Mobil di Wilayah Kota Bandar Lampung. Jurnal Tekno Kompak, 13(2), 1-6.

Alita, D., Fernando, Y. and Sulistiani, H. (2020) 'IMPLEMENTASI ALGORITMA MULTICLASS SVM PADA OPINI PUBLIK BERBAHASA INDONESIA DI TWITTER’, 14(2), pp. 86-91.

Borman, R. I. et al. (2018) 'Implementasi Internet Of Things pada Aplikasi Monitoring Kereta Api dengan Geolocation Information System’, pp. 322-327.

Rahmanto, Y. and Hotijah, S. (2020) 'LAMPUNG BERBASIS MOBILE', 1(3), pp. 19-25.

Sitanggang, I. S. et al. (2020) 'Garlic Land Suitability System based on Spatial Decision Tree', (Conrist 2019), pp. 206-210. doi: 10.5220/0009908002060210.

Pasaribu, A. F. O., Darwis, D., Irawan, A., \& Surahman, A. (2019). Sistem Informasi Geografis untuk Pencarian Lokasi Bengkel Mobil di Wilayah Kota Bandar Lampung. Jurnal Tekno Kompak, 13(2), 1-6.

Ariyanti, L., Satria, M. N. D., \& Alita, D. (2020). SISTEM INFORMASI AKADEMIK DAN ADMINISTRASI DENGAN METODE EXTREME PROGRAMMING PADA LEMBAGA KURSUS DAN PELATIHAN. Jurnal Teknologi dan Sistem Informasi, 1(1), 90-96. 


\section{BIOGRAFI PENULIS (11 PT)}

\begin{tabular}{|c|l|}
\hline $\begin{array}{c}\text { Penulis Pertama } \\
\text { Photo }(3 \mathrm{x} 4 \mathrm{~cm})\end{array}$ & \\
\hline $\begin{array}{c}\text { Penx }(9 \mathrm{pt}) \\
\text { photo(3x4cm) }\end{array}$ & Xxxx $(9 \mathrm{pt})$ \\
\hline $\begin{array}{l}\text { Penulis ketiga } \\
\text { photo(3x4cm) }\end{array}$ & Xxxx $(9 \mathrm{pt})$ \\
\hline
\end{tabular}

